\title{
Przyczepność powłok miedzi na podłożu aluminiowym naniesionych metodą LPCS
}

\section{Bond strength of copper coatings deposited on aluminum alloy with LPCS method}

\section{Streszczenie}

Metoda niskociśnieniowego natryskiwania na zimno (ang. Low Pressure Cold Spraying - LPCS) umożliwia nanoszenie powłok z miękkich metali, takich jak Sn, Zn, $\mathrm{Al}, \mathrm{Cu}$, ewentualnie $\mathrm{Ni}$ i $\mathrm{Fe}$, oraz ich stopów. W procesie zaleca się stosowanie domieszki ceramiki do proszku metalu, w celu polepszenia właściwości mechanicznych uzyskanych warstw oraz zwiększenia wydajności procesu. Budowanie warstw z samego proszku metalu jest również możliwe. W pracy badano wpływ zastosowanego proszku na właściwości mechaniczne oraz mikrostrukturę uzyskanych powłok, naniesionych przy stałych parametrach procesu. Skupiono się na wykonaniu powłok miedzianych, które są powszechnie stosowane w elektrotechnice. Wykorzystano komercyjne proszki dendrytyczne; proszek $\mathrm{Cu}$ z domieszką $\mathrm{Al}_{2} \mathrm{O}_{3}$ (w proporcji obj. $50 \% \mathrm{Cu} / 50 \% \mathrm{Al}_{2} \mathrm{O}_{3}$ ) o granulacji $-45+15 \mu \mathrm{m}$ oraz proszek $\mathrm{Cu}$ o granulacji $-50+15 \mu \mathrm{m}$, którymi pokryto stop aluminium AA1350. Przeprowadzone analizy miały na celu określenie przyczepności warstw oraz ich mikrotwardości. Powłoki były odrywane zgodnie z normą PN-EN 582, bez obróbki powierzchni. Warstwy natryskiwano przy wykorzystaniu manipulatora, co umożliwiło uzyskanie równomiernie nałożonej powłoki.

Słowa kluczowe: metoda niskociśnieniowego natryskiwania na zimno, przyczepność powłok, mikrotwardość, mikrostruktura

\section{Abstract}

Low Pressure Cold Spraying method (LPCS) allows build coatings with soft metals such as $\mathrm{Sn}, \mathrm{Zn}, \mathrm{Al}, \mathrm{Cu}$, even $\mathrm{Ni}$ and $\mathrm{Fe}$ and their alloys. In the process admixture of ceramics to the metal powder is recommended to improve mechanical properties of deposited coatings and increase deposition efficiency. Building coatings with pure powder without ceramic is also possible. In the manuscript the influence of used powder on mechanical properties and microstructure of obtained coatings, deposited with constant process parameters is presented. Copper coatings were deposited, which are commonly used in the electrical engineering. Two kinds of commercial available dendritic powders, $\mathrm{Cu}$ powder with $\mathrm{Al}_{2} \mathrm{O}_{3}$ admixture $\left(50 \% \mathrm{Cu} / 50 \%\right.$ vol. $\left.\mathrm{Al}_{2} \mathrm{O}_{3}\right)$ with a particle size of $-45+15 \mu \mathrm{m}$ and pure $\mathrm{Cu}$ powder with a particle size of $-50+15 \mu \mathrm{m}$ were used in the tests. Aluminum alloy AA 1350 was used as a substrate. The aim of the research was to identify coatings bond strength and microhardness. The bond strehgth tests consisted in pulling off the coatings in accordance with standard PN-EN 582 without coating surface machining preparation. In the spraying process manipulator was used, what gives uniformly deposited coatings.

Keywords: Low Pressure Cold Spraying method, coating bond strength, microhardness, microstructure

Mgr inż. Marcin Winnicki; mgr inż. Aleksandra Małachowska; dr inż. Małgorzata Rutkowska-Gorczyca; prof. dr hab. inż. Andrzej Ambroziak - Politechnika Wrocławska. 


\section{Wstęp}

W metodzie niskociśnieniowego natryskiwania na zimno (ang. Low Pressure Cold Spraying) cząstki proszku pozyskują prędkość ze strumienia sprężonego gazu (powietrza lub azotu) o zadanej temperaturze, a następnie uderzają w podłoże. $W$ procesie nie ma udziału wysokich temperatur, dzięki czemu cząstki osadzane są na podłożu w stanie stałym. Proszek jest jedynie podgrzany przez przepływający gaz. Energia w procesie pozyskiwana jest z wysokiej prędkości przepływającego przez dyszę gazu. Budowanie warstwy jest możliwe po przekroczeniu przez cząstki prędkości dźwięku, co umożliwia dysza de Lavala o specjalnym kształcie zbieżno-rozbieżnym (rys. 1). Istotne jest, aby proszek został wprowadzony do dyszy w pobliżu przewężenia, co gwarantuje pozyskanie przez jego cząstki wysokiej prędkości. W metodzie LPCS stosuje się ciśnienie do 0,9 MPa. Temperatura podgrzania gazu mieści się $w$ przedziale od temperatury otoczenia do $650^{\circ} \mathrm{C}[1 \div 3]$. Zaleca się stosowanie mieszaniny proszku metalu z ceramiką, co pozwala uzyskać korzystniejsze właściwości naniesionej warstwy [3].

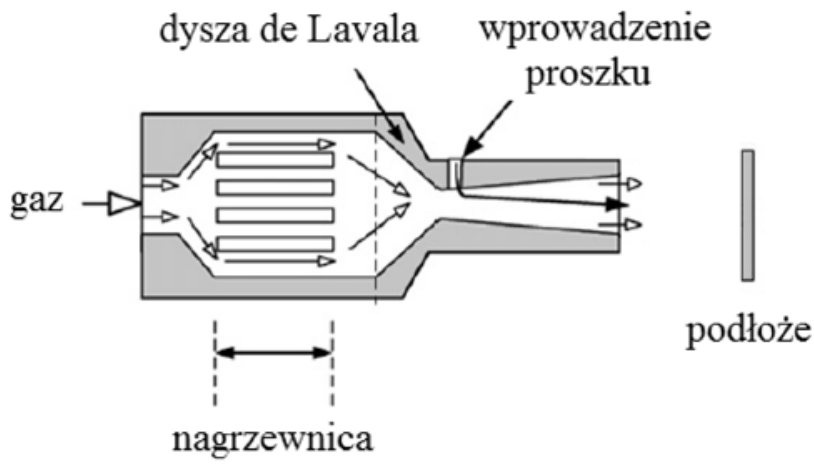

Rys. 1. Metoda niskociśnieniowego natryskiwania na zimno LPCS [2] Fig. 1. Low Pressure Cold Spraying method (LPCS) [2]

Mechanizm łączenia następuje wskutek intensywnej, lokalnej deformacji materiału na granicy cząstki i podłoża, zachodzącej podczas uderzenia ziarna w podłoże. Dochodzi wtedy do powstania pasm adiabatycznego ścinania. Umożliwia to usunięcie tlenków przez tworzącą się wypływkę i tym samym zetknięcie czystych metalicznie powierzchni $[4,5]$. Poza połączeniem mechanicznym dodatkowo mogą wystąpić inne mechanizmy wiązania, np. lokalne wiązanie metalurgiczne, o którym pisze Hussain [6]. Na wartość adhezji ma wpływ wiele parametrów, do których można zaliczyć m.in: materiał podłoża i jego przygotowanie, materiał natryskiwanego proszku, parametry procesu, podgrzanie podłoża przed natryskiwaniem czy też obróbkę cieplną naniesionych warstw.

Innym czynnikiem mającym wpływ na przyczepność powłok w przypadku metody niskociśnieniowej jest ilość dodatku ceramiki do proszku metalicznego. Spełnia ona trzy funkcje: aktywuje powierzchnie usuwając tlenki, ubija cząstki metalu, jak również zapobiega zapychaniu dyszy. Dlatego wraz ze wzrostem zawartości ceramiki w proszku dochodzi do znacznej poprawy właściwości adhezyjnych powłoki $[3,7 \div 15]$. Najkorzystniejsze właściwości zaobser- wowano w przypadku dodatku $50 \%$ obj. ceramiki $\mathrm{Al}_{2} \mathrm{O}_{3}$ [9]. Dodatkowo wraz ze wzrostem fazy ceramicznej obserwowano zmianę typu pękania w próbach odrywania powłok $z$ adhezyjnego na kohezyjny w warstwie aluminiowej [10].

Podawane aktualnie w literaturze wartości adhezji dla procesu niskociśnieniowego natryskiwania na zimno sięgają nawet powyżej $60 \mathrm{MPa}$ dla warstw cynku

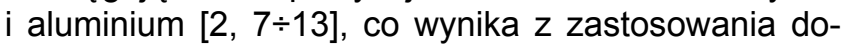
mieszki ceramiki. Przyczepność warstw miedzi jest znacznie niższa i zależy od postaci zastosowanego proszku. W przypadku proszku o składzie $\mathrm{Cu}+50 \%$ $\mathrm{Al}_{2} \mathrm{O}_{3}$ naniesionego na piaskowane podłoże stalowe przyczepność wynosi odpowiednio $32 \mathrm{MPa}$ dla proszku sferycznego Cu o granulacji $-25+5 \mu \mathrm{m}$ oraz $18 \mathrm{MPa}$ dla proszku dendrytycznego Cu o granulacji -63 $\mu \mathrm{m}$ [9].

Wciąż jednak $w$ literaturze jest niewiele informacji na temat przyczepności powłok, jej związku z parametrami procesu, jak również materiałem podłoża i natryskiwanego proszku. Szczególnie niewiele informacji na ten temat dotyczy warstw naniesionych metodą niskociśnieniowego natryskiwania na zimno. Stąd też w niniejszym artykule skupiono się na badaniu przyczepności warstw naniesionych z dendrytycznego proszku miedzi w dwóch postaciach, czystego $\mathrm{Cu}$ oraz mieszanki $\mathrm{Cu}+\mathrm{Al}_{2} \mathrm{O}_{3}$.

\section{Metodyka badań}

Warstwy natryskiwano za pomocą urządzenia do niskociśnieniowego natryskiwania na zimno Dymet 413. Urządzenie to wyposażone jest $w$ palnik $z$ wewnętrznie osadzoną nagrzewnicą oraz dyszą de Lavala o średnicy wylotowej $\varnothing 5 \mathrm{~mm}$. Palnik podłączony był do manipulatora pracującego w 3 osiach $(x, y, z)$. Jako gaz roboczy wykorzystano powietrze. Parametry natryskiwania zestawiono w tablicy I. Schemat ułożenia poszczególnych przejść palnika względem podłoża przedstawiono na rysunku 2 . Odległość między ściegami wynosiła $3,7 \mathrm{~mm}$, dzięki czemu poszczególne ściegi nachodziły na siebie.

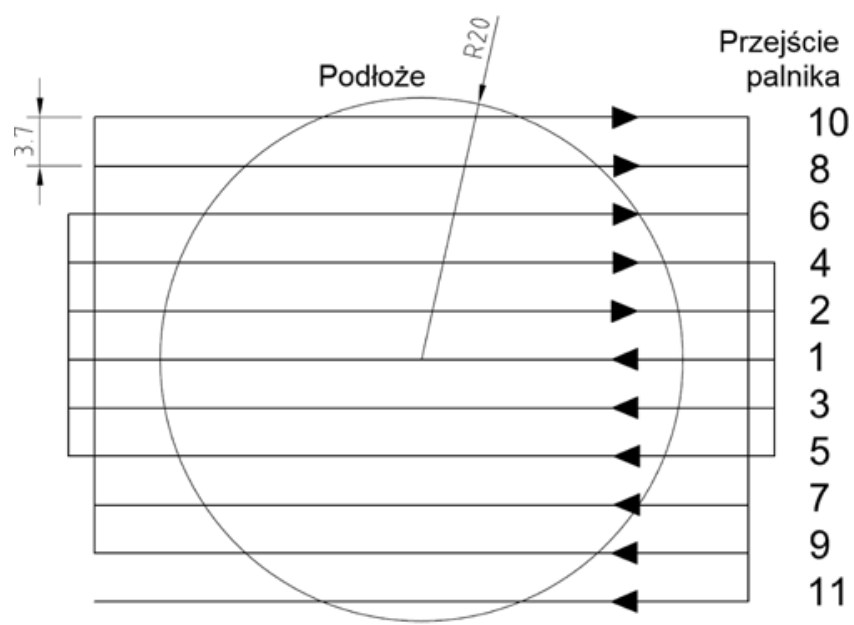

Rys. 2. Schemat ułożenia poszczególnych przejść palnika Fig. 2. Arrangement of individual burner passes 
Tablica I. Parametry procesu LPCS

Table I. LPCS process parameters

\begin{tabular}{|c|c|c|c|c|c|c|c|}
\hline \multirow[b]{2}{*}{ Proszek } & \multirow[b]{2}{*}{$\begin{array}{c}\text { Liczba } \\
\text { warstw } \\
\text { w powłoce }\end{array}$} & \multirow[b]{2}{*}{$\begin{array}{l}\text { Podgrzanie } \\
\text { podłoża }\end{array}$} & \multicolumn{5}{|c|}{ Parametr procesu } \\
\hline & & & $\begin{array}{c}\text { Temperatura } \\
\text { gazu } T,{ }^{\circ} \mathrm{C}\end{array}$ & $\begin{array}{c}\text { Ciśnienie gazu } \\
\text { p, MPa }\end{array}$ & $\begin{array}{c}\text { Odległość } \\
\text { palnika od } \\
\text { podłoża l, mm }\end{array}$ & $\begin{array}{c}\text { Masowe natężenie } \\
\text { podawania proszku } \\
\mathrm{m}, \mathrm{g} / \mathrm{min}\end{array}$ & $\begin{array}{c}\text { Prędkość } \\
\text { liniowa palnika } \\
V, \mathrm{~mm} / \mathrm{min}\end{array}$ \\
\hline $\mathrm{Cu}+\mathrm{Al}_{2} \mathrm{O}_{3}$ & 1 & - & \multirow{2}{*}{600} & \multirow{2}{*}{0,9} & \multirow{2}{*}{10} & \multirow{2}{*}{40} & \multirow{2}{*}{10} \\
\hline $\mathrm{Cu}$ & 3 & $100^{\circ} \mathrm{C}$ & & & & & \\
\hline
\end{tabular}

W badaniach zastosowano komercyjnie dostępne proszki następujących metali: $50 \% \mathrm{Cu}+50 \%$ obj. $\mathrm{Al}_{2} \mathrm{O}_{3}$ o granulacji $-45+15 \mu \mathrm{m}$ (wartość średnia $27 \mu \mathrm{m}$ ) oraz Cu o granulacji -50+15 $\mu \mathrm{m}$ (wartość średnia 31 $\mu \mathrm{m}$, rys. 3). Oba proszki zostały wytworzone w sposób redukcji elektrochemicznej, z tym że proszek $\mathrm{Cu}$ (rys. $3 b) z$ dodatkowym rozdrabnianiem. Proszek $\mathrm{Al}_{2} \mathrm{O}_{3}$ był przygotowany w procesie kruszenia i pozyskał kształt nieregularny. Materiał podłoża stanowił krążek ze stopu aluminium AA1350 (tabl. II) o średnicy ø40 mm i grubości $7 \mathrm{~mm}$. Powierzchnia podłoża przed natryskiwaniem została odpowiednio przygotowana przez obróbkę strumieniowo-ścierną, dzięki czemu uzyskała chropowatość $R a=6,45 \mu \mathrm{m}$.

Badanie właściwości adhezyjnych wykonano dla powłok falistych, ponieważ powłoki łuszczyły się podczas procesu obróbki toczeniem. Jako grubość wyjściową przyjęto $500 \mu \mathrm{m}$. Dla każdej próbki wykonano taką liczbę warstw, aby ostateczna powłoka miała minimalną grubość ok. $500 \mu \mathrm{m}$. Badania zostały wykonane przez próbę zrywania powłok, zgodnie z PN-EN 582 Natryskiwanie cieplne. Określanie przyczepności metodą odrywania. Wartość adhezji wyznacza się jako stosunek maksymalnego obciążenia do powierzchni przekroju próbki. Próba zrywania służy do oceny wpływu materiału warstwy oraz podłoża, jak również warunków procesu natryskiwania [16]. Do przygotowania próbek wykorzystano klej utwardzalny na zimno Distal o średniej wytrzymałości $50 \mathrm{MPa}$.

Mikrostrukturę oraz mikrotwardość badano w powłokach wykonanych z jednej warstwy. Badania metalograficzne przeprowadzono na skaningowym mikroskopie elektronowym (SEM) Phenom G2 pro. Pomiar mikrotwardości wykonano na Digital Micro Hardness Tester MMT-X7 firmy Matsuzawa Co., Ltd. Przekroje metalograficzne przed analizą były trawione zgodnie z PN-75/H-04512, natomiast mikrotwardość mierzono wg PN-EN ISO 6507-3:2007P.

Tablica II. Skład chemiczny stopu aluminium AA1350 (wt. \%, wg PN-EN 573-3:2010P)

Table II. Chemical composition of aluminium alloy AA 1350 (wt. \%, acc. to PN-EN 573-3:2010P)

\begin{tabular}{|c|c|c|c|c|c|c|c|}
\hline $\mathrm{Si}$ & $\mathrm{Fe}$ & $\mathrm{Cu}$ & $\mathrm{Mn}$ & $\mathrm{Cr}$ & $\mathrm{Zn}$ & $\mathrm{Ti}$ & $\mathrm{Al}$ \\
\hline 0,12 & 0,24 & 0,02 & 0,01 & 0,01 & 0,07 & 0,02 & reszta \\
\hline
\end{tabular}
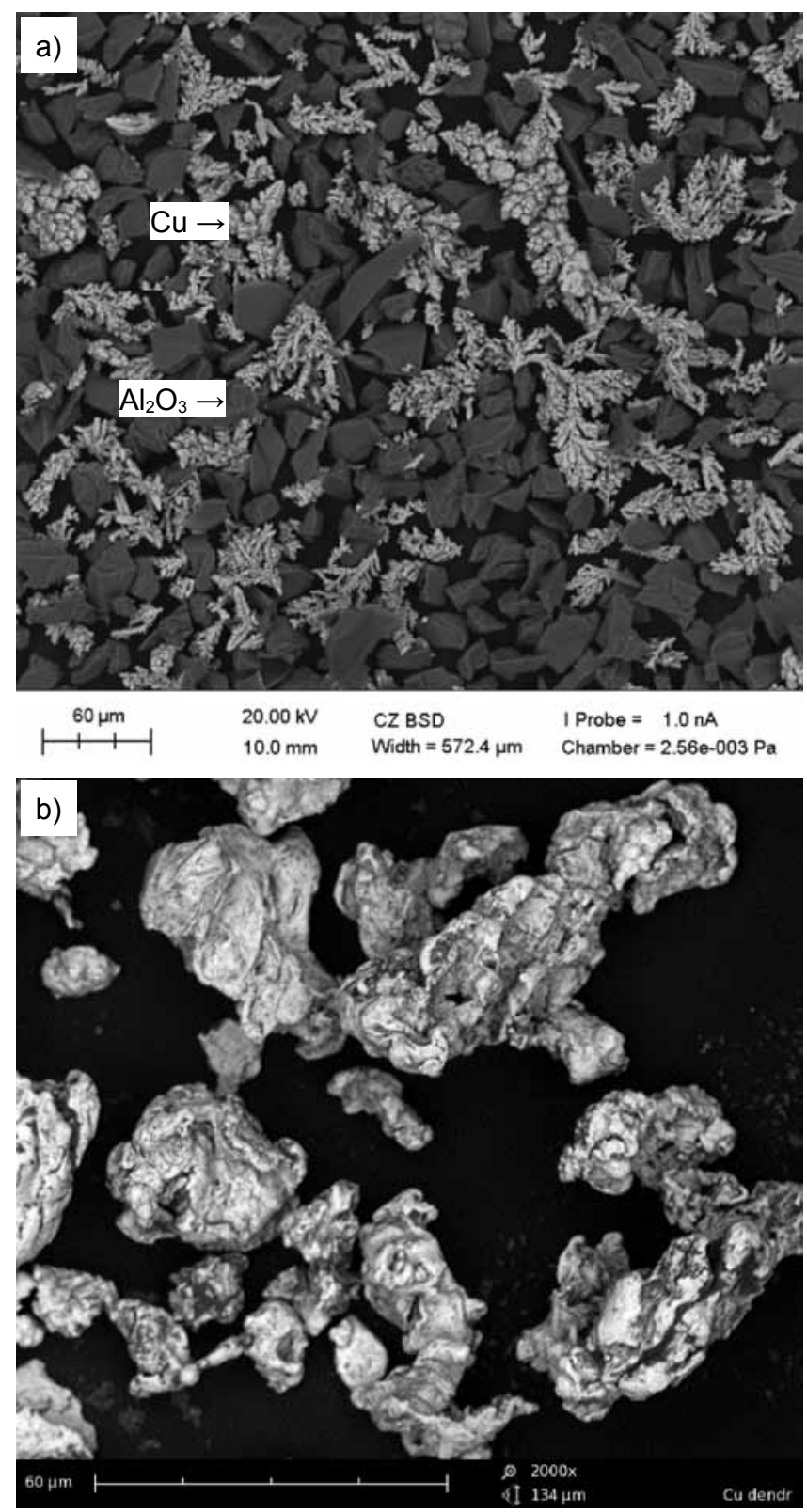

Rys. 3. Morfologia proszków zastosowanych w procesie natryskiwania LPCS: a) $\mathrm{Cu}+\mathrm{Al}_{2} \mathrm{O}_{3}$, b) $\mathrm{Cu}$

Fig. 3. Powders morphology used in LPCS process: a) $\mathrm{Cu}$ $\left.+\mathrm{Al}_{2} \mathrm{O}_{3}, \mathrm{~b}\right) \mathrm{Cu}$ 


\section{Analiza wyników badań}

Wyniki badań przyczepności warstw do podłoża przedstawiono w tablicy III. Na podstawie uzyskanych wyników można zauważyć, że dodatek korundu do ku budowania powłok $\mathrm{z}$ proszku $\mathrm{Cu}$, uprzednio należało podgrzać podłoże do temperatury $100^{\circ} \mathrm{C}$ przed natryskiwaniem. W przeciwnym przypadku energia procesu była zbyt niska i ziarna odbijały się od podłoża. Obecność ceramiki w powłoce $\mathrm{Cu}+\mathrm{Al}_{2} \mathrm{O}_{3}$ przyczyniła się znacznie do wzrostu przyczepności, dla której uzyskano średnią wartość $24,81 \mathrm{MPa}$. Natomiast w przypadku powłok natryskiwanych samym proszkiem $\mathrm{Cu}$ średnia przyczepność osiągnęła zaledwie 10,87 MPa.

Powłoki natryskiwano, wykonując pierwszy ścieg w osi próbki, co miało umożliwić równomierny rozkład ciepła w materiale podłoża. Większa ilość ciepła podwyższa energię procesu, dzięki czemu uzyskuje się wyższą wydajność natryskiwania oraz przyczepność do podłoża. Na rysunku 4 przedstawiono przełomy warstw. Powłoka wykonana z czystej miedzi ma typowo adhezyjny przełom, natomiast powłoka $\mathrm{Cu}+\mathrm{Al}_{2} \mathrm{O}_{3}$ adhezyjno-kohezyjny. Jak można zauważyć, w obu powłokach zerwanie zapoczątkowane jest w miejscach rozpoczęcia nakładania pierwszego ściegu, który oznaczono strzałkami. W przypadku powłoki $\mathrm{Cu}+\mathrm{Al}_{2} \mathrm{O}_{3}$ przełom adhezyjno-kohezyjny postępuje od podłoża do wewnętrznej części powłoki. W obszarach, gdzie podłoże było bardziej nagrzane, doszło do zerwania kohezyjnego. Prawdopodobnie zwiększenie energii procesu przez podgrzanie podłoża $w$ obu przypadkach do temperatury powyżej $100^{\circ} \mathrm{C}$ powinno

Uzyskane mikrotwardości obu warstw odbiegały znacznie od mikrotwardości zastosowanego proszku, która wynosiła odpowiednio dla Cu z mieszanki 72,2 HV0,01 (odch. stand. 9,94) oraz $\mathrm{Cu}$ czystego 78,1 $\mathrm{HV0}, 01$ (odch. stand. 8,6). Dla warstw $\mathrm{Cu}+\mathrm{Al}_{2} \mathrm{O}_{3}$ wartość mikrotwardości mieści się w przedziale 119,4 HV0,2 $\div 129,0$ HV0,2, natomiast w przypadku zastosowania proszku $\mathrm{Cu}$ w przedziale 120,3 HV0,2 $\div 121,8$ HV0,2. Wyższa mikrotwardość materiału w warstwie

Tablica III. Wyniki próby zrywania warstw Table III. Results of coating pull-off tests proszku ponad dwukrotnie zwiększył przyczepność uzyskanych powłok. Należy podkreślić, że w przypadzwiększyć przyczepność warstwy.
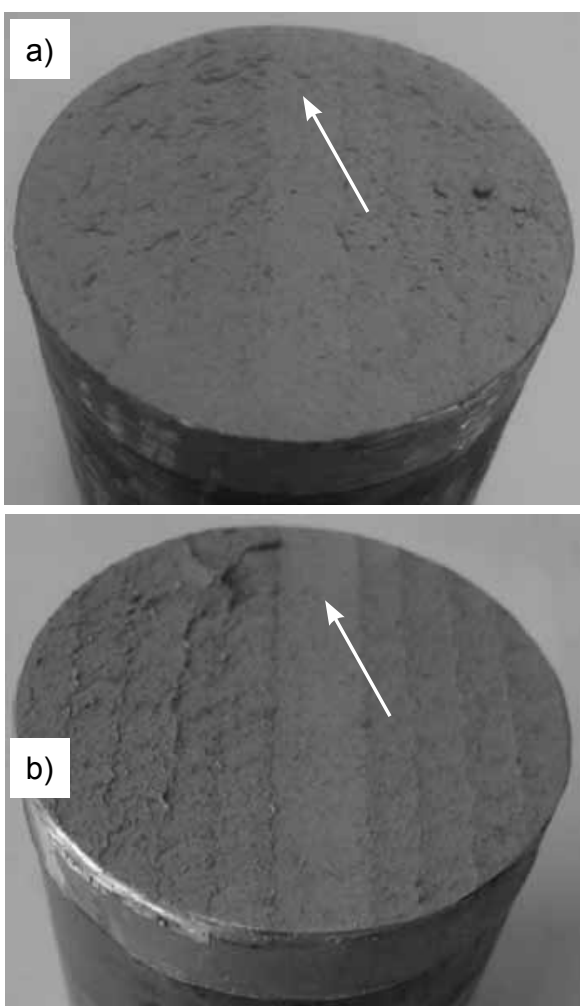

Rys. 4. Wyniki próby zrywania warstw LPCS: a) $\mathrm{Cu}+\mathrm{Al}_{2} \mathrm{O}_{3}$, b) $\mathrm{Cu}$ Fig. 4. Results of LPCS coatings pull-off tests: a) $\mathrm{Cu}+\mathrm{Al}_{2} \mathrm{O}_{3}$, b) $\mathrm{Cu}$

spowodowana jest zgniotem podczas natryskiwania, co wywołuje utwardzenie. W przypadku warstw zawierających korund odnotowano wyższą mikrotwardość w strefie przejściowej między podłożem a warstwą, czyli w obszarze tzw. międzywarstwy, co wynika z obecności ceramiki w natryskiwanym proszku (rys. 5). Korund lokalnie wbijał się w podłoże, powodując intensywniejszy zgniot cząstek $\mathrm{Cu}$.

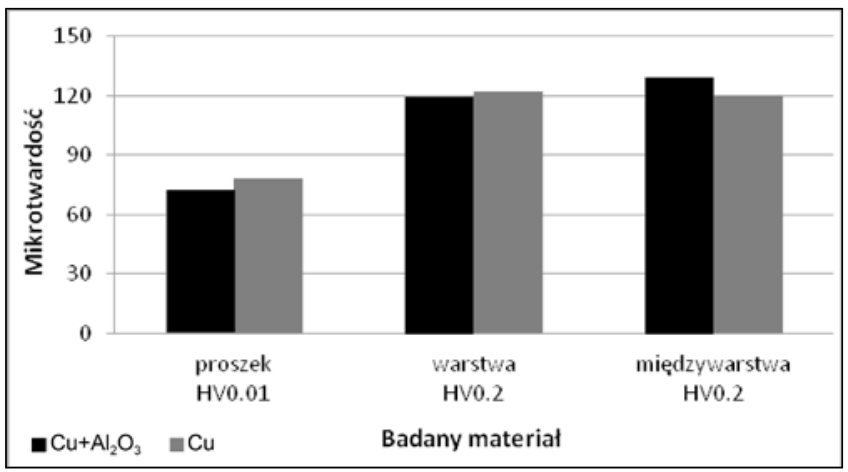

Rys. 5. Wyniki pomiarów mikrotwardości

Fig. 5. Results of microhardness measurements

\begin{tabular}{|c|c|c|c|c|c|c|c|}
\hline \multirow{2}{*}{ Proszek } & \multirow{2}{*}{ Próba } & \multicolumn{2}{|c|}{ Grubość powłoki, $\mu \mathrm{m}$} & \multirow{2}{*}{$\begin{array}{c}\text { Siła zrywająca } \\
\mathrm{N}\end{array}$} & \multirow{2}{*}{$\begin{array}{l}\text { Przyczepność } \\
\text { powłoki, MPa }\end{array}$} & \multirow{2}{*}{$\begin{array}{c}\text { Wartość średnia } \\
\qquad \mathrm{MPa}\end{array}$} & \multirow{2}{*}{$\begin{array}{l}\text { Odchylenie } \\
\text { standardowe }\end{array}$} \\
\hline & & $\min$ & $\max$ & & & & \\
\hline \multirow{3}{*}{$\mathrm{Cu}$} & 1 & 510 & 960 & 13340 & 10,62 & \multirow{3}{*}{10,87} & \multirow{3}{*}{0,57} \\
\hline & 2 & 480 & 880 & 13160 & 10,47 & & \\
\hline & 3 & 470 & 760 & 14470 & 11,51 & & \\
\hline \multirow{3}{*}{$\mathrm{Cu}+\mathrm{Al}_{2} \mathrm{O}_{3}$} & 1 & 470 & 860 & 28820 & 22,93 & \multirow{3}{*}{24,81} & \multirow{3}{*}{1,69} \\
\hline & 2 & 490 & 1120 & 31760 & 25,27 & & \\
\hline & 3 & 470 & 980 & 32950 & 26,22 & & \\
\hline
\end{tabular}


Grubość warstw wykonanych z proszku $\mathrm{Cu}+\mathrm{Al}_{2} \mathrm{O}_{3}$ mieściła się w przedziale $470 \div 1120 \mu \mathrm{m}$. Badania metalograficzne wykazały, że mimo postaci dendrytycznej proszku warstwa zawiera zadowalającą strukturę wolną od porów (rys. 6). Czarne nieregularne punkty w mikrostrukturze to faza $\mathrm{Al}_{2} \mathrm{O}_{3}$. Można zaobserwować, że drobne ziarna korundu osadzają się w dużej ilości między poszczególnymi ziarnami miedzi, tworząc lokalne zbrojenia. Lokalne aglomeracje ceramiki mogą doprowadzić do powstania kruchego obszaru w strukturze warstwy. Na rysunku 6b zaznaczono obszar miedzi bez korundu, która niemal całkowicie wypełnia przestrzeń w warstwie. Spowodowane jest to dodatkowym zgniotem, który powoduje obecność ceramiki w proszku. Przeprowadzono również analizę zawartości korundu przy powiększeniu warstwy 550x. Okazuje się, że w naniesionej warstwie występuje jedynie ok. $10 \% \mathrm{Al}_{2} \mathrm{O}_{3}$. Porównując $\mathrm{z}$ mieszanką proszku, gdzie występowało $50 \% \mathrm{Al}_{2} \mathrm{O}_{3}$ (obj.), jest to znaczny

a)

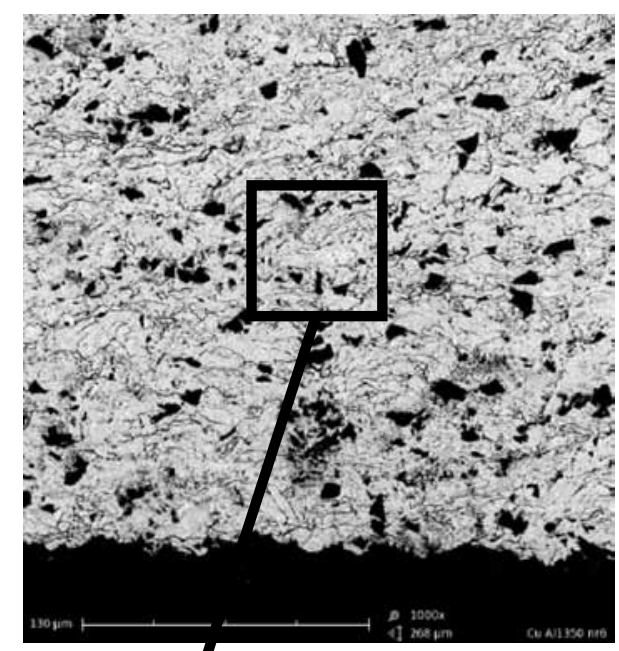

b)

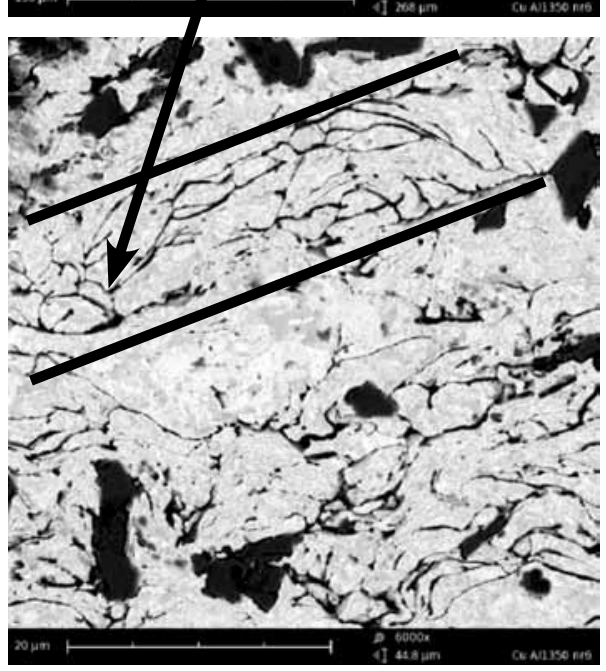

Rys. 6. SEM warstwy $\mathrm{Cu}+\mathrm{Al}_{2} \mathrm{O}_{3}$, powiększenie: a) $1000 \mathrm{x}$, b) $6000 \mathrm{x}$ Fig. 6. SEM images of $\mathrm{Cu}+\mathrm{Al}_{2} \mathrm{O}_{3}$ coating magnified: a) $1000 \mathrm{x}$, b) $6000 \mathrm{x}$ spadek. Większa część korundu z proszku odbija się od warstwy, stanowiąc ubytek materiału przy natryskiwaniu.

Warstwy Cu miały grubość 149 $\div 385 \mu \mathrm{m}$. Cząstki proszku tworzą zadowalającą strukturę, jednak widać większą ilość porów niż w warstwach $z$ domieszką ceramiki (rys. 7). Potwierdziła to analiza porowatości w obu warstwach. W przypadku powłok budowanych z samego proszku Cu porowatość wyniosła aż $20 \%$ (rys. 7b), natomiast dla powłok zawierających korund porowatość osiągnęła $6 \%$. Twardość obu zastosowanych proszków była na zbliżonym poziomie, stąd decydujący wpływ na równomierne wypełnienie warstwy musiała mieć domieszka ceramiki w proszku. Ponadto ceramika zwiększyła trzykrotnie wydajność procesu. W celu wykonania powłoki o grubości $500 \mu \mathrm{m} z$ prosz$\mathrm{ku} \mathrm{Al}_{2} \mathrm{O}_{3}$ wystarczyło nanieść jedną warstwę. W przypadku zastosowania proszku bez korundu konieczne było osadzenie trzech warstw.

a)

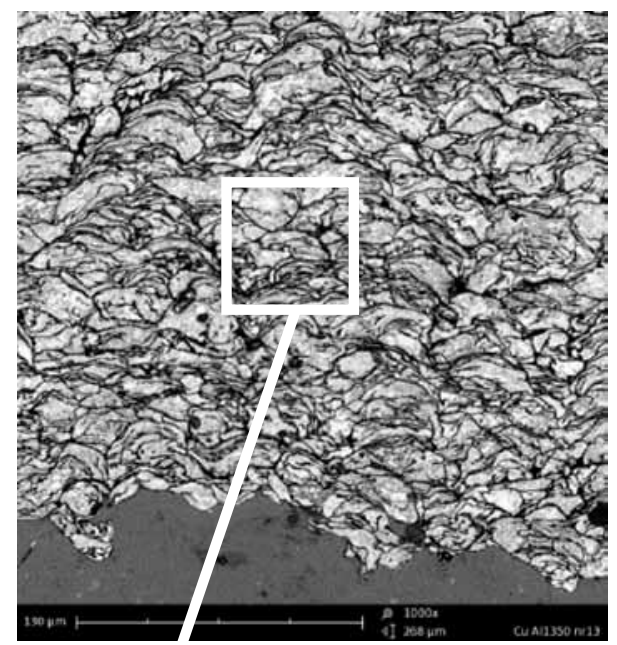

b)

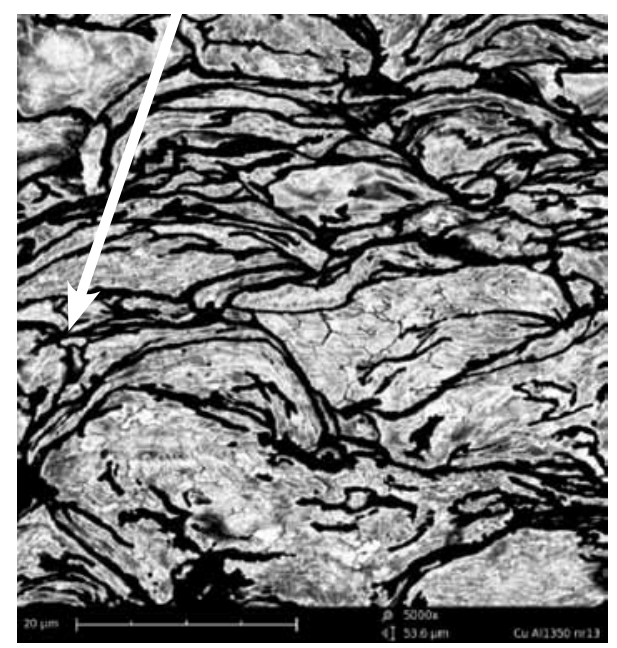

Rys. 7. SEM warstwy Cu, powiększenie: a) 1000x b) 5000x

Fig. 7. SEM images of Cu coating magnified: a) 1000x, b) 5000x 


\section{Wnioski}

Badania wykazały, że proszek $\mathrm{Cu}+\mathrm{Al}_{2} \mathrm{O}_{3}$ pozwala uzyskać powłoki o ponad dwukrotnie wyższej przyczepności do podłoża, dochodzącej do $25 \mathrm{MPa}$, od powłok wykonanych z samej miedzi. Zastosowana domieszka ceramiki ma korzystny wpływ nie tylko na wzrost przyczepności powłoki. Powoduje również zmniejszenie zawartości porów w uzyskanej powłoce, a także znaczne zwiększenie wydajności procesu, co widać po liczbie naniesionych warstw w celu uzyskania powłoki o grubości $500 \mu \mathrm{m}$.

Warstwy LPCS cechują się wysoką twardością, która przekracza niemal dwukrotnie twardość materiału rodzimego proszku. Wynika to z intensywnego zgniotu i odkształcenia ziaren podczas natryskiwania. Należy podkreślić, że obecność fazy korundu w proszku metalu nie spowodowała znacznego wzrostu twardości metalu w powłoce.

Analiza mikrostrukturalna pokazała, że naniesione powłoki $\mathrm{z}$ proszku $\mathrm{Cu}+\mathrm{Al}_{2} \mathrm{O}_{3}$ cechują się dużą gęstością i małą porowatością. Powłoki wykonane z miedzi bez dodatku korundu nie wypełniają równomiernie przestrzeni w warstwie, czego skutkiem jest większa porowatość.

\section{Literatura}

[1] T. Schmidt, F. Gärtner, H. Assadi, H. Kreye, Development of a Generalized Parameter Window for Cold Spray Deposition, Acta Mater. 54, 2006, s. 729 $\div 742$.

[2] Xian-Jin Ning, Jae-Hoon Jang, Hyung-Jun Kim, The effects of powder properties on in-flight particle velocity and deposition process during low pressure cold spray process, Applied Surface Science, 2007, vol. 253, s. 7449 $\div 7455$.

[3] H. Koivuluoto, J. Lagerbom, M. Kylmalahti, P. Vuoristo, Microstructure and Mechanical Properties of Low-Pressure Cold-Sprayed (LPCS) Coatings, Journal of Thermal Spray Technology, vvol. $17(5 \div 6)$, 2008, s. $721 \div 727$.

[4] H. Assadi, F. Gärtner, T. Stoltenhoff , H. Kreye, Bonding mechanism in cold gas spraying, Acta Materialia 51 (2003), s. $4379 \div 4394$.

[5] M. Grujicic, C.L. Zhao, W.S. DeRosset, D. Helfritch, Adiabatic shear instability based mechanism for particles/substrate bonding in the cold-gas dynamic-spray process, Materials and Design 25 (2004), s. $681 \div 688$.

[6] T. Hussain, D. McCartney, P. Shipway, D. Zhang, Bonding Mechanisms in Cold Spraying: The Contributions of Metallurgical and Mechanical Components, J. Therm. Spray Technol., 18(3), 2009, s. $364 \div 379$.

[7] H. Mäkinen, J. Lagerbom, P. Vuoristo, Adhesion of Cold Sprayed Coatings: Effect of Powder, Substrate, and Heat Treatment, Thermal Spray 2007: Global Coating Solutions: Proceedings of the 2007 International Thermal Spray Technology, 2007, Beijng, China.

[8] X.-J.Ning, J.-H. Kim, H.-J. Kim, C. Lee, Characteristics and heat treatment of cold-sprayed Al-Sn binary alloy coatings, Applied Surface Science 255 (2009), s. 3933 $\div 3939$.
[9] H. Koivuluoto, P. Vuoristo, Effect of Powder Type and Composition on Structure and Mechanical Properties of $\mathrm{Cu}+\mathrm{A}$ $\mathrm{I}_{2} \mathrm{O}_{3}$ Coatings Prepared by using Low-Pressure Cold Spray Process, Journal of Thermal Spray Technology, vol. 19 (5), 2010 , s. $1081 \div 1092$.

[10] Q. Wang, K. Spencer, N. Birbilis, M.-X. Zhang, The influence of ceramic particles on bond strength of cold spray composite coatings on AZ91 alloy substrate, Surface \& Coatings

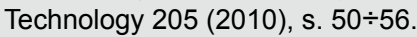

[11] K. Spencer, D.M. Fabijanic, M.-X. Zhang, The use of Al-AIO cold spray coatings to improve the surface properties of magnesium alloys, Surface \& Coatings Technology, vol. 204 2009, s. 336-344.

[12] E. Irissou, J.-G. Legoux, B. Arsenault, Ch. Moreau, Investigation of Al-Al2O3 Cold Spray Coating Formation and Properties, Journal of Thermal Spray Technology, vol. 16 (5-6), 2007 , s. $661 \div 668$.

[13] H. Koivuluoto and P. Vuoristo, Effect of Ceramic Particles on Properties of Cold-Sprayed $\mathrm{Ni}-2 \mathrm{CCr}+\mathrm{Al}_{2} \mathrm{O}_{3}$ Coatings, Journal of Thermal Spray Technology, vol. 18 (4), 2009, s. $555 \div 562$

[14] L. Pawłowski, The Science and Engineering of Thermal Spray Coatings, John Wiley \& Sons Ltd, Chichester, 2007.

[15] R.G. Maev, V. Leshchynsky, Introduction to Low Pressure Gas Dynamic Spray, WILEY-VCH Verlag GmbH \& Co. KGaA, Weinheim, 2008

[16] Norma PN-EN 582: Natryskiwanie cieplne. Określanie przyczepności metodą odrywania, Polski Komitet Normalizacyjny.

\section{Miesięczne i roczne spisy treści oraz streszczenia artykułów opublikowanych w Przeglądzie Spawalnictwa są dostępne na stronie internetowej:}

$$
\text { wWw.pspaw.ps.pl }
$$

